\title{
Pain, Grip, Pleading
}

\author{
Kuang-Ming Wu \\ Philosophy Department, University of Wisconsin-Oshkosh, Oshkosh, USA \\ Email: Kmwu2002@yahoo.com
}

Received 19 March 2015; accepted 22 April 2015; published 23 April 2015

Copyright (c) 2015 by author and Scientific Research Publishing Inc.

This work is licensed under the Creative Commons Attribution International License (CC BY). http://creativecommons.org/licenses/by/4.0/

(c) ()

\begin{abstract}
Pain is an open grip pleading with the beloved. "Pain, grip, pleading" is triune family-kinship to give birth to existence.
\end{abstract}

Keywords

Pain, Grip, Pleading, Open, Family

\section{Introduction}

Socrates was "benumbed (narkao)" by his own "sting ray" of enlightening a slave boy (Meno 84b); I was stung by the triune "pain, grip, pleading" here. These three themes drawn from Christianity hit us at our guts, away from Christianity proper. Tiny kids are instinctively drawn to someone, and toddle out telling of him. The pages below are toddling body thinking on how hard we are hit by a strange man called "Jesus."

From him three powerful incredulities come on us to hit us hard. They are God in "family-pain" congenial to Japan and China, Jesus' tight grip of us, totally open, and our Father from the vast sky pleading with us. Such is the logic of the coming of concern; it is a family-phenomenology of ultimate care inescapable, engulfing us all. These incredible themes are human, all visceral human, far beyond mere doctrinal Christianity.

\section{Pain}

Let us visit exotic Japan for the reputed Japanese theology, a "theology of the pain of God." On the cross, God-in-man cried after God-in-love, who in such pain "gave his only begotten Son, so that those who believe in him would not perish but have everlasting life” (John 3:16). Kazoh Kitamori 北森嘉藏 (b. 1916) caught this pain in his "theology of the pain of God" (Dohi, 1991). Significantly, this theology of God's pain was published one year after Japan's defeat in WWII; God was in pain with Japan's deserved defeat. But the book tells of nothing on it. When young, I read this book with passion in Japanese original; it was rhetorically sensational. The page citations here are from its English translation that partially shows its original expressive sparkles (Kitamori, 1965). Good for him! But we are stunned to find in it nothing Japanese. Criticizing him leads us to 
God's pain as fatherly family-pain congenial to Japan. So, Japanese theology found not Japanese guides us into Japan. Such irony! Let us first criticize him, and then see how our criticism oddly guides us into Japan.

Kitamori shouts "the pain of God" never carefully explained; he mentions points, undefined. Catchy irresponsible epigrams are collected unconnected. He belabors the obvious and contorts the straight simple. I could bend over backward to take his wrong phrase, "love rooted in pain," as "love we understand as rooted in pain we experience as a symbol of love, all mystery." But such contortions miss the flesh-and-blood Jesus; his viscera twist as he touches us to heal us, and dies his actual death in agonies on the cross. He then rises up alive with nail-marked hands, eats fish, and bakes fish for us at dawn of his bodily resurrection. Where is the love-mystery of pain-symbols?

Aside from these complaints on his methods, his contents abound in defects. God's pain manifests God's love, God's "essence" never rooted in pain, much less is it pain itself. The reason is simple. "Person in pain" does not show how the person is "rooted" in pain; "necessity to suffer pain" does not show pain as the "essence" of the person who suffers.

God's pain is visceral (Jeremiah 31:20) (Kitamori, 1997), nothing “mystical,” yet a chapter "The Mysticism of Pain" (pp. 71-84) is on pain; this chapter is a scattered hotchpotch, unintelligible. Strangely, Kitamori (1997) never mentions the visceral pain (splanchnizomai) of Christ himself and his visceral presentations of his mercy-parables, appeared no less than 12 times in Synoptic Gospels. "Mystic" is known (as not-cognitive) but "mysterious" is unknown; he confuses the two. History, ethics, and eschatology are derived from God's pain, yet a complete chapter is devoted to each of these themes, and many chapters are on "ethics" alone, while he has no complete chapter on pain itself.

He often beats around his self-concocted bush, going into nothing. He tried (pp. 34-35) to piggyback his self-concocted "God's worldly pain from God's pain” on to Anselm's "God's existence from God-concept”; is he alone unaware that the pious Kant had, with "being (existence) is not attribute” (Kant, 1965) already punctured Anselm? Such needless vanity he noisily committed!

"In Matthew (Mt) 25 Jesus said helping people helps him, and Mt 26 says we leave people to help him; Kitamori says God immanent (Mt 25) is God transcendent (Mt 26)," in his short Chapter 8 with a long title. But, of course, the same Jesus says both; Kitamori just repeats the problem. Then he adds our sin to our pain; the problem still stays. He noisily beats around theo-logically; he ss logically unforgivable.

Crucial phrase, "Japanese theology" in p. 7 appears undefined, but citing two chapters 3, 11; "tsurasa" is criticized in Chapter 11 and Chapter 3 just mentioned Japan (Kitamori, 1994). "Tsurai" is cruelty to others, pain, and difficulty (Kitamori, 1994). Kitamori (1994) made a big splash on it; adds unneeded "fate." All this is a mess. In any case, Kitamori must not confine "Japanese theology" to two chapters. Greek theology is pervasively Greek in thinking-mode, all different from Roman theology. Japanese theology must be all Japanese in style in content.

He said his book was written "during World War II" (p. 12), but not how significant this book is to this Japanese devastation. Tragically, almost all citations are European, in whose terms Japanese church and its translations are criticized. Reading this book reads a Western theology, more rhetorical less clear. Kitamori's "theology" shouts the "Wolf! Wolf!" emergencies of faith, seldom looking after daily faith-essentials.

To the question, "Does God's pain belong to God the Father, or God the Son, or to both? If both, how is their pain distributed?”, Kitamori (p. 115) says, God's pain is pain of both God the Father and God the Son, in whom God the Father is hidden. How are "both" Father and Son related? How could pain be "hidden"? Has he explained God's pain itself? After all, God's pain is the Cross of Christ; the theology of the cross has been tried all over since the church fathers. What else is new, especially in Japan?

Kitamori discovered that God is in pain; this is his contribution, for no one has linked God almighty to pain human. "Isn't the entire passion of Christ ritualized in the Catholic stations during the Easter, precisely the celebration of God's pain?” Well, precisely this doctrinal ritualization has blocked our noticing God's pain as sheer pain so human. Trying to protect itself with doctrines, Christianity ironically loses itself. Kitamori's merit lies in restoring God's pain to pain all-divine yet all-human.

But all too sadly, Kitamori himself did miss God's pain as pain concrete. He takes pain as a general category in a Western conceptual way, while pain is concrete, personal, and specific. Taken as a general category, pain turns bloodless universal, unintelligible; Kitamori has to wallow aimlessly in general themes of ethics, eschatology, and history, all distantly related to pain, if any.

He needs to anchor God's pain concretely as "family pain," which is the genius of Sino-Japanese culture and at the center of the Bible; sadly, Kitamori the Japanese misses the Japanese feature in the Bible. He avidly de- 
tails Greek Trinitarianism theoretically distant if not unbiblical (no such word in the Bible), unaware that Greek Trinitarianism only adumbrates, at most, Japan's family love made divine.

Our world has only two "family cultures," Jewish-Christian and Sino-Japanese, and God our Father used Jewish-Christian family-culture for Asians to spread to Sino-Japanese family-culture and beyond. Of all people, the Japanese Kitamori did miss this Gospel family-fact! Matthew and Luke begin with genealogies, to tell us that the Good News is rooted in the family-tree of God with us humans since the cosmos was created by God's family-love.

And then, our Brother Jesus' story of the Prodigal Son in Luke 15 tells of the family tragedy unfilial to our divine Father. Bad children are still the father's children; good children complaining are also the father's children. This family-story is told by God the Son our Brother Jesus, to later culminate in him killed by us his brothers, on the cross the worst punishment of worst criminals, tragically imposed on Jesus the greatest lover of us all.

Such "sin" makes no sense till sensed as family tragedy of patricide and fratricide. Kitamori's favorite, Jeremiah's "pain" (31:20), is God's family pain on "my son," who is we his bad children. Pain is rooted in love (not love in pain, as Kitamori keeps saying!), and love is abstract bloodless till crystallized as "family love" precious special, as Japanese people viscerally know. Isn't family-love the rationale of the Incarnation of God's fatherly love, since its creation of all as “one family under God the Father”? Isn't this the structural rationale of Japanese theology?

Kitamori sees God's pain, and then incredibly misses God's pain as parental so obviously there, so congenial so central to Japan where loyalty at all levels extends family ties. Missing the biblical centrality of family-pain, he criticizes Japanese tsurasa-pain as missing one pole in God's pain (pp. 136-138) the supposedly "universal pain of God" abstruse distant; he tragically missed an obvious concrete family-pain of God.

Christianity is all family loyalty, centrally stressed as the cultural core in China and Japan, as China's time-honored Filiality Classic 孝經 and the Great Learning 大學 poetically sum up. The Judeo-Christian theology is Sino-Japanese filial piety writ divine, and then (not before then, as Kitamori did!) we can worry about the Christian symbolism of "writ divine," to wit, Japanese theology as exemplifying the Incarnation of God the Father's love; Japanese theology is a ready offshoot of God's family-love homo-cosmic.

Kitamori the Japanese is tragically all-blind to such Japanese family-sentiment starkly pervading the whole Bible, right to Kitamori's Japanese face. No word "family" appears at all in his book touted as "Japanese theology”! He is obligated to Europe more contorted, indirect, alien to family-love, and less biblical. "Japanese theology" still belongs to the future of Japan and of the world. I am sorry to have to be negative about my brilliant fellow Asian.

"Now, we are busy. What is the point of your tedious complaints?" Sorry, but the above complaints tell of two points quite crucial. One, my complaints prove my failure to find Japan in a Japanese theology of Kitamori. Two, lack of Japan in a Japanese theology ironically "guides" us to Japan's family-culture, found to pervade the Bible. Kitamori's two failures alert me on two points. One, pain is not his conceptual universal but concrete and specific. Two, God's pain is the family tragedy congenial to Sino-Japanese culture he misses.

"But how do you know that God's pain is family-pain? Besides, isn't 'family' common to all cultures, not just Judeo-Christian or Sino-Japanese, since we are all born and raised in families?” You have raised two points, my friend. Here are my responses. First, all "pain of God" in the Bible is centered in the family-context, including Kitamori's favorite Jeremiah 31:20 that centers on "my son."

Secondly, being born and raised in a family is never equivalent to stressing family love, family duty, and family pain. Not every world culture stresses family-love. Only Judeo-Christian and Sino-Japanese cultures centrally and explicitly stress family-love, both as fact and as our innate duty, as their cores at our existential cores. Both these points can be explained by the following two "spinoffs."

"Family in the Bible" has two spinoffs; both are novel and crucial. The first is on Old Testament (OT). "Family" pervades the Bible, and so, all family-cultures can serve as OT. The world has two family-cultures, Jewish-Christian and Sino-Japanese; the family-classics in China can be Asian OT to parallel Jewish OT. We must then, as a second spinoff, probe the peculiar family-features in the Bible.

The first spinoff is on the OT. The Jews have their OT full of family-love (of God our Father to us, and of our duty of family-love to revere Father-God and to love our fellow siblings). Christianity is a vast "family business"; under God the Father, we are all brethren. "Filial piety 孝道” in China and Japan backs up reverence to the Father in Heaven who is Asian "Heaven 天," the First Greatest Ancestor whom we must obey absolutely, 
reverently.

China and Japan can thus adopt Filiality Classic 孝經, Rite Record 禮記, and the Four Books 四書 as the Sino-Japanese OT. "Isn't filiality and brotherliness the root of humane conduct?" (Analects 1/2); the "root" is recognizable as family-Christianity. "Filiality" is the First Commandment to worship God our Father; "brotherliness" is the Second Commandment to love my neighbors my brethren as myself. The New Testament (NT) supplies our Father's incarnation in our brother Jesus the Christ.

The pain of God in Jesus' cross is the "family tragedy" viscerally familiar in Sino-Japanese culture, and so, fit to be OT to NT that details the heavenly family. Jewish OT has our disobedience; Asian OT has our reverence. Both these OTs supply the background to fratricides and patricide (NT), as both these family-OTs are fulfilled by the NT of family-acts.

The second spinoff is on the "family in the Bible" itself. Every family differs from every other. What is the specifically peculiar content of "family in the Bible"? The rest of this essay answers this crucial query with two stunning points in NT, family grip of Brother Jesus, and family pleading of Heavenly Father being pushed by the Beyond, as its family-business homo-cosmic.

\section{Grip}

Religion demands our ultimate commitment to one ultimate alone, absolutely closed to all other ultimate religions; but if there exists a religion of ultimate openness, we can embrace open commitment. Unbelievably, in the name of God the Father of us all, Jesus came to doggedly open to us all. The orthodox people correctly told Jesus never to mix with-open to-incorrect sinners, as Jesus kept mixing with sinners and even praised some Roman soldiers, Nazi CIAs. Praise opens.

Jesus then told these correct people that they, too, must quit closing and be happy with shady sinners. It was such an affront that they gave Jesus the worst death possible, to show publicly how closed to incorrect people their "correct religion" is. But, dying in agony, Jesus was still open, even praying for them who crucified him, "Father, forgive them, for they don't know what they are doing!" (Luke 23:34).

And then, Jesus came back alive, still obstinately gripping us with his hands now marked as pierced with nails of correct people trying to stop him. His stiff-necked openness defying death is his love "stronger than death" to climax the ode to love (Songs 8:6). His strangest strongest stubbornness is his commitment to openness. If we accept him accepting us-incorrect, we would embrace his "open commitment" stronger than death. The religion of ultimate love is the religion that is unconditionally, deathly, open.

By unconditionally accepting us all totally unworthy, this parental love of God, in brotherly love of Jesus, forgives us to accept us, by way of — can we believe this?_-dying for us sinners, and for those "correct orthodox" sinners who killed Jesus. Can you believe that the correct orthodox people are sinners? But it is the fact if our God is our Father who opens to us all, his children, to whom those orthodox people are closed.

Jesus accepts us-absolutely open to us - until he dies, and still accepts us beyond his death. Accepting us beyond death is ultimate acceptance, in the religion of openness. He still— "still” is powerful!—keeps accepting us, after his resurrection, with his open hands staying nail-marked as he ascends to the right hand of God his Father our Father. All this while, his nailed hands keep tightly gripping us, never let us go, literally forever, totally divinely forever.

Never think that Jesus' grip is easy; his grip is sheer pain, splanchnizomai, as with Mencius' "pain at heart unbearable” 不忍人之心, and “pained heart and soul” of Taiwanese love, “I pain you 我疼你.” Pain in the guts grips me as I grip you, and you, and you here now, not "he," "she” or "they." I totally close in with my fully open hands as I grip you, and such close-open tension is my gut-pain.

But none deserves pain without good reason; much less should anyone desire pain capriciously. Pain remains outside human territory. "Do I desire to grip, then?” The answer is strange but inevitable: "I cannot help it.” I live on love such as self-love, and my living-on grips me, often in pain. Pain in grip is my be-all of living in love that spreads by gripping you. What oppose Jesus all-open is correct people closed. Jesus is obstinately open as the sky, in pain sky-vast.

China reveres “top-one-big 天 $[=-$ + 大 $]$ Heaven.” We are “one family under heaven 天下一家” under Jesus. "Heaven" differs from Jesus in that heaven has no hand no nail-marks of pain, as he grips us with his heaven-hands nail-pierced. "Heaven” is China's exalted ultimate, but China does not realize heaven as open, much less its dictate 天命 on us all to open to bad people and good-closed people, even to our death in pain. 
Not affected by such treasure it has, China spoils this treasure, as USA has democracy to betray it, as we live to spoil life by not fulfilling our life-responsibility to open to all people. We live "under heaven” to spoil heaven to spoil ourselves, and not even know it; we are so lost that we do not know we are lost. Heaven-Jesus, come back alive from death by correct closed-people, is here to grip us with his open hands nail-marked, in sheer pain.

Jesus at the beach is still baking fish we caught, "Here, breakfast-it!" (John 21:12); we breakfast heaven under Jesus! It is my translation of the original, just two words, so crisp, so direct, and so intimate that "no one dares to ask anything," this verse continued. We have heavenly hope beyond death, back home where we have begun living. Life’s beginning is “mother and child” irresistible essential. Mom grips her baby as her essence, as her baby naturally grips Mom. “Are they in pain?” Mom "gut pains” her baby who cried in pain when born out of her.

Both Mom and her baby are closely bound all open, you in me, I in you, gripping at each as the self. Mother and child compose the primal begin-all be-all of humanity, the glue of life stronger than death than hell (Songs 8:6). Their grip is primal love. It is how all of us humans began living gut-grip for grip that not even death can separate. As I live breath to breath with a tree, I look up at it in admiration; you are my tree of life.

I remain "I" to breathe you in to enrich myself into "I," not choking me into you. I dwell in you and I become more of "I" in you than alone. I cannot live without you my tree, under Mother Nature my life-milieu, as a baby grows under Mom his life-milieu. You are my milieu my dwelling my gripping, my breathing open arms closing-in. I need you my milieu my “motherly all” to be embraced alive as I.

I die bereft of my pain of gripping love, breathing you in. In your open grip, you let me be me, as Mom nurtures her baby her be-all to grow as the baby all his own. Mom grows in her baby, as he brushes her away, to toddle to stumble to be picked up, gripped tight, and kissed tenderly. Mom's grip lets the baby grow into him in her, who keeps mumbling, "I pain you, sugar."

My Apa-Dad, my Abu-Mom, and you and I compose a "family" our milieu where we all grow, inter-gripping firmly openly, never let “you” go, to let you be “you.” We are at home in each other breath to breath, as we let each grow into each. Only Mom can lug this baby of hers around so casually so seriously. Without her baby, Mom dies. Without you my parents and my beloved, I would not have begun to live, to grow up as "I" in you. But Judas betrayed Jesus, as orthodox fury did betray Jesus, and Jesus gripped even such destructions of his open grip, on the cross. But what did Jesus do to Judas? The Bible did not say. Perhaps the true grip is tested here in the smashing of the grip; how far can the grip go?

Love's grip viscerally moves its recipient. Zacchaeus (Luke 19:1-10) may be one of the dirtiest ruthless of swindling "tax collectors"; he is oddly attracted to the rumored joys of dirty sinners with Jesus. He climbed secretly up a tree to take a peek. Jesus also strangely feels Zacchaeus' heart. Jesus stopped at his tree, looked up to him, and shouts, “Come down, Zacchaeus! I must stay at your house tonight!” Wow! What shock! Quickly climbing down, standing before the crowd, Zacchaeus declared in joy, "Lord, I give half of my stuff to the poor; and if I defrauded anyone, I pay fourfold”; it was sharing opposed to his life, irrelevant to meeting Jesus.

But Zacchaeus sensed the crux of the matter, overwhelmed by Jesus accepting him. His declaration admits his dirt now cleansed! Jesus' open pursuit has borne another fruit, as is in John 4 where he also overwhelmed a dirty lady into shock into joy, turning her into an ambassador of Jesus’ pursuit of the despised Samaritans. “The Son of man came to seek and to save," says Jesus also in sheer joy (Luke 19:10). On this interesting phrase of his, see "son of man” (Friedrich, 1972).

Here Jesus has three open-verbs, “came, seek, save,” all-gripping. “Coming” is decisive, imminent, compelling, never far from me, "seeking saving” in his open grip of me. "Seeking” opens out pursuing us all; "saving” grips me to allow me to be me fully. People’s jeers, "Save yourself!” under the cross was actually fulfilled by him saving us, one by one. Saving us "saves him" who is love.

Once it bites in, a bulldog never lets go of what it bites, even pounded to death; beyond-bulldog is Jesus who grips us to his death to beyond death, to save us from death beyond death. His love of us is much stronger than death; "much stronger" is his divine stubborn grip through death beyond death. His hands are wide open seeking pursuing us from our inside, in his visceral pain, obstinately-embracing us all over — to save us by giving all his self.

Jesus keeps hugging us in his Father who keeps creating us into us; his “death to life-again” is his open commitment to us. Jesus is still coming, in open grip. “No more losing you, never again!” gripping us from inside till his death beyond death; he is still coming in eternal dawn of my new life, in his resurrection morning far more stunning than poetic ecological "news of the universe” (Bly, 1980). This is great news of Mother Nature. 
I am breathless announcing from rooftops his coming into me into you. He comes into you with the totality of me now a forgiven sinner, saved accepted in his open arms, nail-marked by correct people. This stupendous happening to me to you is my cosmic crisis in my beginning-all, my be-all, and my end-all, to seep to you, to you, world without end.

To him I am one precious family member of God the Father. I would cling on to him as Mary Magdalene-I so envy her! - did at the empty garden at dawn of his coming-back. I am home at last. His relentless grip, against persecutions by correct decency, is relentlessly open to all people, including correct people. Jesus' grip till he dies and rises alive is his "open grip" of us all.

Jesus enfolds me to enable me as love creates me to let me be me, to spread to you, and you. His embracing grip is his open commitment, to enable us to be totally open to others, religiously other or those in various needs. Jesus can wash Budda's feet and die for him; Buddha can take Jesus as "nothing.” In this way, both can shake hands standing inter-opposite. But this is not Boorstein deleting Creator God of jealous love to become a nirvanic Buddhist (Boorstein, 1997). Now I cannot live if I cannot serve; service is my begin-all, my be-all, and my end-all. Jesus is incarnated in me (commitment) to serve, as I serve my enemies (open).

It is open commitment, our love against all orthodoxy, smashing deaths to "make all things new"; "sea" of pain vanishes to make for joys of inter-support. All is kid's Wonderland in logical non-sequiturs inter-mesh topsy-turvy, grabbing fighting playing. Here we inter-disagree to inter-learn, to inter-enrich. We live it; we die it. "It" is Jesus washing our dirty feet and baking fish at his dawn alive. We are fed to serve with open hand; we can now commit us to those nearby, till pierced in our hands, in the name of our sins accepted forgiven by his nail-pierced hands.

Open commitment smashes closure to others. It makes sense as all things are created by family love-love creates - of creative love as "father" of all, all for nothing. Creation of all implicates openness to all, by Jesus' all-open hands with nail marks, inflicted by our "correct orthodoxy" closed to all incorrect people. This religion of open commitment has such logic of love so twisty so simple.

\section{Pleading}

“Isn't this stubborn grip arbitrary, though? Do you have any rationale for the grip?" Very good, pal, that you nudge me to this good query! Jesus' tight grip is not arbitrary but has a heavenly reason of heavenly family. His grip is sharing enjoined by our Father who created all things as a family; we are all brethren, and what we have must be co-owned in family co-grip, to shape us all. Family-love sky-high is the rationale sky-high of Jesus' stubborn grip beyond death.

In one interpretation, Proverb 3:27 says someone's need is that someone's right to own (Scott, 1965); it is logically absurd (his need is his right) and ethically deep (we must share). The fault of correct people is that they refused to share in holier-than-thou pride, blind to "we all are brethren under the sky." Separation is crime against humanity; "sharing" is natural, simply extending my hands that routinely help my own needs, tiny, various, and all-indispensable.

Sharing is economy inevitable, technology at work, all essential to inter-thriving. We do it unawares; we must share consciously, naturally as picking things for others from the floor of other's needs. All this is care-logic in family-love. Concretely, Jesus' "prodigal son" parable has a son-father dialogue outside home, for the son refuses to go home, hearing his prodigal brother now home and their father is spreading feast.

And so, the father came out to plead (Luke 15:29-32), to move me to tears. The son shouts, "Look! I've been loyal all these years; you never gave me a tiny goat for fun with pals. But your terrible son ruined your possessions and came back, and you at once killed a fat calf!" His father warmly pleaded, "My son, you are always with me; all that is mine is yours. But your brother was dead now alive, lost now found. Come, we all must celebrate!"

The big brother correctly argues on justice, separating him right from others wrong. The father pleads on family-love, embracing all. The big brother complains on injustice to "me"; Job is here, complaining rejecting his father's family-warmth, shivering chill, loveless outside. And then, his father comes out to give all love, forever waiting (for younger son) and pleading (with older son). All the father has is all Job's the elder brother's. Even if evil people prosper, they remain lost outside love in justice; and the father keeps seeking as the shepherd and the lady in the two parables before this one.

We on earth separate matters, we vs. they, fair vs. unfair, inventing evil to accuse God, and then defend God in our theodicy. We debate with heaven in self-pride; our Father in the sky all-inclusive comes out to "plead" 
with us. Pleading of the Almighty Creator Father with creatures—-tiny, helpless, and mortal—stuns us to turn our world upside down.

"My son, you have been with me as you have been under the sky. All I have-in heaven, on earth, everything -is yours. But you must care for your brethren. Care pains in co-pain (Merriam-Webster's Collegiate Dictionary, 2008; Oxford English Dictionary, 2001). I have been searching; let us seek them out, shall we?” That pleading by our Almighty Father melts away our tiny pride, as it did Job, in family love homo-cosmic so vast so awesome.

Our Heaven our Father is still pleading with us, even in our killing him in his dearest God the Son incarnate. Still he comes, and comes again from his death—we killed him! —still to seek us out to plead with us, so that we would accept his pleading, to convey his pleading to every sister and brother every single day. His pleading continues through us, persistently, to calm us in joy.

We are after all kids of Heaven; doing the bidding of our father fulfills us. The sky has no fence; our father comes to us fence-less, unconditional, to plead with us to come back home to our sky. Marriage is made in heaven; family-care is sky-vast. Our home our sky is the outer space rooming us, constantly pleading with us; we must accept all our brethren as the vast sky vastly accepts us all. "And please share. Freely given, freely give; gripped, share grip. The more you share, the more you own!”

And the pleading continues. "Do you see billions of stars up there? You can own them if you share them, OK? How do you share? Go tell your sisters and your brothers about all I tell you! That is how you share the vast sky and countless stars. Go! Plead sky-vast with them all. You can have as many stars as you can see-each star is vastly bigger than the earth you live—as long as you share, spreading my pleading!”

Our Heaven our Father is right now still pleading with us from his heart of hearts! Such incredible love we meet in the universe! We keep bumping into the family-love far beyond this earth we live, extending far beyond all lives. Family acceptance is unconditional as the sky. Marriage is made in heaven; the family lives the sky. Our Father heavenly pleading with us to accept him, to accept our brethren, is natural as we live "under heaven" (China); duty to love neighbors as myself is natural as I live under heaven (Judeo-Christianity).

Innate self-love under heaven composes my intimate immediacy of family-care for my neighbor my family. I cannot escape extending my self-love as I cannot escape the sky over us all. Love of all my fellow-beings is decreed by heaven I live under. Such is the heavenly rationale of heavenly Father pleading with me and with every "me" my neighbor my family, in his Son's open grip so stubborn.

"But if all this neighbor-love as my family-love is obvious as I live under the sky, why does the heaven-father have to plead with me to do so?” I do not know the answer. Unbelievably, Heavenly Father has to plead, and he is still pleading, and we are still struggling to respond properly. Our absolute divine imperative remains, that we must heed Heavenly Father's pleading in his Son's grip, on pain of our own demise.

"But how can we love our neighbor as I love myself?” This question remains as the most crucial, doesn't it? Our heartfelt heeding of his pleading may give us the power to obey him to inter-accept, as unconditionally joyously as he accepts us as his children. We just yield to his tight embrace sky-open. Yielding sounds defeat; family-"defeat" wins our integrities, to spread to all family under the family-sky under our Father. All this is what China has been stressing all along, as Confucius did. I am crafting an essay, "Global Family in Confucius for Today" (Wu, 2015).

Jesus' family-yielding is self-emptying for to fulfill all. Jesus never killed a single person; Jesus kills no demon, even, as he drove them out. Two cases of non-human deaths have symbolic significance. The Gerasene demons are allowed to enter pigs to their deaths to show how more precious persons are than non-humans (Matthew 8:28-34, Mark 5:1-20, Luke 8:22-25). A fig tree is withered due to no fruit out of its season for Jesus, to show that we must bear fruit in and out of season (Matthew 2:18-20, Mark 11:12-14, 20). Taking a person as a demoniac relieves us of accusing him as bad; it is demon's fault, not his. But this is how sadly Heavenly Father's pleading has fared. Let us repeat; we cannot repeat this story often enough. The correct orthodox people are horrified at Jesus mixing freely with shady trash, laughing, and even eating with them!

These highbrows tell Jesus, "We must draw a firm line of right from wrong, never to deal with those hoodlums, prostitutes the social rejects, Syro-Phoenicians the dogs, tax-collectors the brutal swindlers, Samaritans the historic outcasts, much less Roman soldiers our enemy, all such trash.” Of course people always draw the line, rightly or wrongly. Jesus was particularly opposed to the right sort of drawing the line as above done. Jesus responded to them warmly, "My dear correct folks so high! Our Heavenly Father's mansion is the sky so high as you, and it has no fence. He has children, we all; bad people are his bad children. Some are happy to come home 
to our warm Father. It is proper and our joy to celebrate our shared homecoming. Come! You come, too!” My god, these correct highbrows get furious, taking Jesus as one of them trashy. Jesus pleads with good people relentlessly, till they had to - to protect their clique—consign Jesus to crucifixion to put away their headache.

Incredibly, Jesus agonizing on the cross prays to his Father for those who kill him, "Father, forgive them, for they do not know what they do!" (Luke 23:34) And then, after three days, Jesus rises alive to still pursue us all with his open arms now nail-marked, right now! This stunning story is dubbed Good News; Jesus even uses his cross to save us from the orthodox drawing of lines, as open sky and its Father have no line.

This story is repeated to show how his grip of us is identical to his Father pleading with us. This grip-inpleading is love stronger than death; love even uses death to pursue us to plead with us. "Come home, my children! Come home, you all, my precious!” Our deicide now depicts his dead-heat pursuit of us to come home to celebrate our family reunion, homo-cosmic and vast beyond.

It is thus that in Jesus' cross begins the New Heaven and New Earth singing praises to God our Father almighty all love, day in and day out, and the night pain-ocean is sung vanished. Jesus is still standing among us, washing our feet our hearts our viscera, with his nail-pierced unsightly hands. Jesus' cross certifies his deathless certainty of his deathless grip of us, however shady and shameful we are.

We go home beyond death! All our loved ones, our adored parents, our revered fore-parents, are waiting, in Jesus who died for them and for us all. We are still alive so as to spread heavenly joys of homecoming to anyone we see. Jesus is all persistent all priceless, vast as high-sky covering us, intimate as our breathing alive with trees. We live his grip; we sleep his embrace. We keep celebrating our homecoming.

And those correct orthodox people who killed Jesus, you come, too! Jesus wants you! His arms with your nail-marks are all open to you, all yours all ours. We must come home, intimate heartfelt. No homecoming to heaven, we simply die as dews. That is why he died for us via correct people killing him; Jesus dying and rising again is his tight grip open to us that is his Father's pleading with us his children.

Jesus wants us each to forgive "each brother" of mine, under "my Father" in heaven, 70 times 7 in heartfelt mercy. Wholehearted forgiveness is a family business of global concord, initiated by our Father in his Son, our Brother Jesus to us to spread through us. This family-love, gripping us all tightly, even beyond death, is Good News of joys sky-high. The joys begins at the birth of Baby Jesus so tender so helpless.

\section{Conclusion}

Thus Kitamori's "pain of God” was family-pain at the root of Kitamori's own Sino-Japanese culture that he incredibly missed. This pain of our innate family that gives birth to us and nurtures us to grow is "under heaven", sky-vast and splanchnic deep. This pain is in the love of Jesus humane divine, always in visceral pain. Visceral pain, "splanchnizomai", is used by Jesus alone and on Jesus alone (Kohlenberger, Goodrick, \& Swanson, 1997). This pain is noticed by Mencius (1A1-7) as pain unbearable at heart.

This pain was shown spontaneously even in Dictator Hui who had to have a bull released because he could not bear the sight of its mortal jitters being dragged to sacrificial slaughter. Such pain is Kitamori's "pain of God", in our innate family, gripping us and pleading with us sky-vast no-boundary, history-continuous. The family-pain comes with Jesus' stubborn open grip nail-marked.

He is pierced-incredibly - by our correct insistence that right must be separated from wrong, and we end up defying his open arms tightly gripping us all, including us the correct people. "Pain-grip-pleading" is a trinity stubborn, family-gripping us all through life beyond death, sky-vast, nature-deep as our root. The "pain, grip, pleading" shapes a phenomenology of the coming, the logic of the invasion of heaven on earth, as it is the structure of the incarnation of family-love, turning the loveless life world upside down. Such vast family revolution is visceral intimate, in personal pain unbearable in our depths of being, in all Joy of all joys.

All these joys continue to happen in silent rebirth-creations spreading inexorable, as family-love gripping us all beyond death. This is serious as divine death into divine rebirth, toward human death into human rebirth. A phoenix divine-human is burned only to rise up from its ashes. We sigh breathless, totally embraced in Jesus' tight brotherly grip, under Heavenly Father's incessant family-pleading.

All such grip in all such pleading always starts at the family where a baby is born, asleep in an animal feedbox, amidst silly hotel noises. All this while, the quiet night of shepherds with their animals is suddenly stirred by huge angel hoopla of joys in the sky, as Luke 2 breathlessly described. The baby grips us; the baby pleads with us. The family with its animal members is heavenly gripping, ever in Joy sky-high. 


\section{References}

Bly, R. (1980). News of the Universe: Poems of Twofold Consciousness. San Francisco: Sierra Club Book.

Boorstein, S. (1997). That's Funny, You Don't Look Buddhist: On Being a Faithful Jew and a Passionate Buddhist. San Francisco: Harper.

Dohi, A. (1991). Theologeschichte der Dritten Welt Japan. Japan: Kaiser Verlag, Tokyo Publishers.

Friedrich, G. (1972). Theological Dictionary of the New Testament. Grand Rapids, MI: Wm. B. Eerdmans.

Kant, I. (1965). Critique of Pure Reason, tr. Norman Kemp Smith. New York: St. Martin’s Press.

Kitamori, K. (1965). Theology of the Pain of God, tr. M. E. Bratcher. Richmond, VA: John Knox Press.

Kitamori, K. (1997). The Greek-English Concordance to the New Testament. Grand Rapids, MI: Zondervan.

Kohlenberger, J., Goodrick, E., \& Swanson, E. (1997). The Greek-English Concordance to the New Testament. Grand Rapids, MI: Zondervan.

Merriam-Webster’s Collegiate Dictionary (2008). Merriam-Webster’s Collegiate Dictionary. http://www.merriam-webster.com/dictionary

Oxford English Dictionary (2001). Oxford English Dictionary. New York: Oxford University Press.

Scott, R. B. Y. (1965). Proverbs: Ecclesiastes, Anchor Bible. New Haven, CT: Yale.

Wu, K.-M. (2015). Global Family in Confucius for Today. In Progress. 